\title{
The Impact of Treasurer's Experience And Knowledge on The Effectiveness of The Administration and Preparation of The Accountability Reporting System in North Sumatera
}

\author{
Azhar Maksum*, Rustam Hamid, \& Iskandar Muda \\ Faculty of Economics and Business, University of North Sumatera \\ J1. Dr. T.Mansur, No.9, Kampus USU, Medan, 20155, North Sumatera, Indonesia \\ *Corresponding Author, E-mail: azhar.maksum@yahoo.com
}

Received: Sep. 22, 2013 Accepted: Oct. 29, $2014 \quad$ Published: December 1, 2014

doi:10.5296/ajfa.v6i2.6341 URL: http://dx.doi.org/10.5296/ajfa.v6i2.6341

\begin{abstract}
This study aims to determine the role of treasurer's experience and knowledge on Permendagri (Minister Regulation) No. 55/2008 to create the effectiveness of administration and preparation of the accountability reporting system. This study is an explanatory survey using primary data. The scope of the study includes the new expanded regional governments, namely; the districts of Batubara, Padang Lawas, South Labuhan Batu and North Labuhan Batu. The effectiveness of the administration and preparation of the accountability reporting system is used as a dependent variable and both treasurer's experience and knowledge are the independent variables. The study population comprises of 310 people where 115 people are selected as the sample using the purposive random sampling method. The study founds that the experience variable does not affect the effectiveness of the administration and preparation of the accountability reporting system; meanwhile, the knowledge variable has an effect on the effectiveness of the administration and preparation of the accountability reporting system.
\end{abstract}

Keywords: Effectiveness of the administration and preparation of the accountability reporting system, Experience and knowledge. 


\section{Introduction}

The efforts to improve the presentation of the regional financial report's submission are increasingly being discussed. This is related to the importance of the governance reform, thus the efforts towards achieving good governance and authoritative have continously been emphasized. Unfortunately, the efforts to reform the financial reporting presentation seems to not have been fully implemented yet by the regional governments as well as the task force units within the regional government. A change in the regional government's accounting approach of single entry into double entry is a fairly revolutionary change. On the other hand, the publication of financial statements by regional governments through newspapers or the Internet does not seem to be a common thing for most regions.

The government realizes this matter, including the efforts made by issuing the regulation of the Ministry of the Internal Affairs, especially related to treasury and governance administration. It is marked by the creation of Permendagri No.55/2008 on the procedures of treasurer's administration and accountability report preparation. All the treasurers (concentrating on receipts and spending) are at the forefront of the implementation of this regulation. A treasurer of task force units which are based on the current regulation is obliged to submit the financial reports 2 months upon the year-end closing of accounts. If the performance is good, then the regional government treasurers' efforts to obtain the opinion of financial statements by the audit board with qualified predicate are not difficult to realize. It is necessary to study the main obstacle of not achieving the qualified predicate from several new expanded districts. Thus, this study is intended to look at the effectiveness of the adminisration and the preparation of the accountability reporting system of regional task force units.

A study by Avazzadehfath et al. (2011) states that the skilled human resources constitute an important factor for an organization. A lot of organizations are always seeking to improve the efficiency of the organizations by sending their employees for training, on a given cost. Their study in Iran has found that the existing system especially for the organization's accounting information system related to the activities of the human resource cycle, will process the data and convert them into practical information. It also finds that the investment decisions are influenced by the presence of the human resource accounting cycle and disclosed in the financial statements. Thus, this concludes that the human resource accounting system which is integrated with the financial reporting cycle contributes to the production of relevant decisions contained in effective reports.

Meanwhile, the findings by Meyta et al. (2013) which examine the fiscal management perspective based on Permendagri No. 59/2007 in the financial management board and the regional asset in Sorong city have concluded that the processes of planning, preparation, implementation, administration, reporting and accountability of budgets in Sorong city have not been fully carried out in accordance with the regulations because of the fact that some changes in the new regulations have not been implemented where they still refer to the old regulation of Permendagri No. 13/2006. This constraint occurs due to the lack of human resources that are reliable and competent in their fields as well as the fact that changes in the regulations have made the financial management cycle failed to run the way it should. 
Kengatharan and Kengatharan (2014) state that human behavior in the aspects of reporting and accountability is a fairly new field. This field is based on the aspect of psychology, in which it tries to understand the emotions and cognitive errors that influence the behavior of individuals. In this context, the behavior becomes an integral part of the decision, because it affects the performance execution. Moreover, Pangkong et al. (2013) examine the factors that affect the ability of the regional government's financial statements in Biak Numfor district of Papua Province. The study proves that partially, the human resource quality affects the ability to prepare the regional government's financial statements in Numfor Biak while the variables of regulatory understanding, commitment and set of supports have no effect.

Next, Kim (2005) examines the individual-level factors and organizational performance of government oganizations in Korea. He explains that the achievement of public sector organizations is determined by their performance on the individuals, thereby providing effective accountability reports. The effectiveness is determined by demographic variables such as age, work experience, gender, education level and occupation of personnel, whereby all of these factors significantly influence the performance of individuals in Korea. Given the arguments above, this study aims to analyze the extent of experience and knowledge of task force units' treasurers on the Permendagri No55/2008 towards the effectiveness on the administration and preparation of the accountability reporting system in the North Sumatera province.

\section{Literature Review}

\subsection{Theoretical Review}

\subsubsection{The Theory of Goal Setting}

The theory of goal setting is part of the motivation theory proposed by Edwin Locke in the late 1960s (Melati, 2011) in Wibowo (2013). This theory asserts that an individual's intention to achieve a goal is a major source of work motivation. An individual with a difficult, more specific and challenging goal will result in higher performance than those with vague objectives such as easy goals that have no specification or purpose at all (Melati, 2011). Locke (1990) in Melati (2011) reveals that there are two categories of actions which are directed by goals, namely: (a) non-conscious directed goal (b) conscious directed goal or purposeful actions. The underlying premise of this theory is the second category of conscious goal, where it unravels the useful ideas to encourage individuals to act (Latham, 2004 in Melati, 2011). Meanwhile, a theory of goal setting assumes that there is a direct relationship between the definition of specific objectives and measurable performance; if the person (managers/officers) know what would exactly be the objectives that they need to achieve, then they will be more motivated to exert efforts that can improve their performance (Locke \& Latham, 2002 in Melati, 2011). The aim of having a challenge is usually implemented in the output, with a specific level to be achieved (Locke \& Latham, 1990 in Wibowo (2013).

\subsubsection{The Achievement Motivation Theory}

According to Samsudin (2005) in Haryanto (2013), motivation serves as a process that influences or as an external push against a person or working group that makes him want to 
implement something which has been set. Motivation is a condition or energy that drives employees' self-directed state that will lead them to achieve organizational goals. Meanwhile, Siegel and Marconi (1989), Carlos (2013) in Wibowo (2013) mention that a motivation is the key to start, control, maintain and direct the behaviors. It is also regarded as a driving force of one's heart, which means that he has the willingness to obtain the success and achieve the goals.

Moreover, Robbins and Judge (2007), Carlos (2013) in Wibowo (2013) have posited that the motivation is a process that describes the intensity, direction and persistence of an individual to achieve his goal. On the other hand, general motivation is associated with any effort to achieve the goal. The three main elements in this definition are the intensity, direction and persistence related to the extent of how hard one works, or attempts at something. A high intensity to produce satisfactory work performance should be associated with a favorable direction. Persistence is a measure of how long a person can maintain his business.

2.1.3. Characteristics of Administration Information Quality and Financial Accountability Report

The characteristics of the Accounting Information System comprise of elements as follows (Hall, 2007):

1. Relevant. This refers to the information that needs to be known to deliver new insights. The reports that are used temporarily and are later on irrelevant are to be eliminated.

2. The right time. The age of information is a critical factor in determining its usefulness. Information should not be older than the period of time that it enables the action to be supported.

3. Accurate. Information should be free of errors that is material by nature. The material errors occur when the amount of information is inaccurate, thus the decision makers tend to make poor decisions or fail to make necessary decisions.

4. Completeness. There is no part of information that is essentially needed in decision making or the execution of a task is missing. Incomplete information can cause difficulties and has an impact to a great element of uncertainty.

5. Summary. Information must be aggregated to fit the user's needs. Concise information and the summary of relevant data show deviations from the areas of the normal level, which is standard or planned as a form of information that is much needed by the users.

\subsubsection{Experience}

An experience refers to the administration and reporting accountability both in terms of the length of time, the number of assignments as well as the kinds of tasks that are handled (Nilawati, 2009). Another definition states that an experience is a learning process and an extension of the potential development of behaviors in both formal and non-formal education or could be defined as a process that brings a person to a pattern of higher behavior. According to Nilawati (2009), the length of treasurer's service and experience in holding a position will render them acknowledged as a person who is responsible for the basic activities in the 
organization's daily operations. The longer duration that the treasurers are holding the position, the better their work performance.

2.1.5. The Knowledge of Permendagri (Ministry of Internal Affair's Regulation) No. 55/2008

In relation to the administration and accountability reporting system aligned with the orderly administration and accountability of the budget implementation, it needs to prepare and submit the administration procedures and accountability reports for the treasurers. The regulation of the Ministry of the Internal Affairs No.55/2008 is a refinement of the regulation of the Ministry of Internal Affairs No.13/2006 on the regional financial management guidelines. This Permendagri was launched in order to control everything related to treasury with the expectations to achieve goals. The regulation will then bring improvement to the regional governance policy and its financial management.

According to Halim (2007) in Pangkong et al. (2013), the government accounting standards (SAP) work as a guideline for the preparation and reporting of budget realization, to both central and regional governments, with the goal of uniformity, synchronization and harmonization of all kinds of reports. Based on the government regulation No. 58/2005 on the regional financial management, the regional government has the authority to develop policies and procedures for the accounting and financial management system in accordance with the regional government's accounting standards. Above all, the regional government may prepare its financial statements in the form of the budget realization report, balance sheet, cash flow statement and notes to the financial statements in accordance with the government accounting standards, accounting policies and financial management systems and procedures, so as to produce transparent and accountable financial statements (Halim et al., 2010). The regulation that relates to the treasury mentioned must at least be understood by those who carry it out.

\subsection{Review of Previous Research}

The matric results of the previous studies are related to the topic of this research as illustrated in Table 1. below: 


\section{Macrothink}

Table 1. Review on Previous Research

\begin{tabular}{|c|c|c|c|}
\hline Auth & Title & Variables & Findings of Research \\
\hline $\begin{array}{l}\text { Nilawati, Ivon } \\
\text { (2009) }\end{array}$ & $\begin{array}{l}\text { A study on delay of Spending } \\
\text { Accountability Report Delay } \\
\text { by the task force units } \\
\text { (SKPD) in Central Lampung } \\
\text { of } 2008 \text {. }\end{array}$ & $\begin{array}{l}\text { The research is } \\
\text { conducted descriptively } \\
\text { not using the dependent } \\
\text { and dependent variables. }\end{array}$ & $\begin{array}{l}\text { The submission activity of spending } \\
\text { accountability report in Central } \\
\text { Lampung region is not running } \\
\text { accordingly based on the applicable } \\
\text { regulations and has frequent timing } \\
\text { inaccuracy in it's submission. The } \\
\text { possible constraints are due to; (i) the } \\
\text { presence of policy in spending } \\
\text { accountability activities in Central } \\
\text { Lampung is considered inappropriate } \\
\text { and inconsistent with Permendagri } \\
\text { 13/2006, and (ii) the lack of ability on } \\
\text { task force units in these activities, } \\
\text { among others, due to the low quality of } \\
\text { human resources and lack of } \\
\text { socialization and training about the } \\
\text { rules of the spending accountability } \\
\text { activities in Central Lampung region. }\end{array}$ \\
\hline $\begin{array}{l}\text { Muda, } \\
\text { Iskandar., } \\
\text { Rasdianto, \& } \\
\text { Muhammad } \\
\text { Safri Lubis. } \\
(2014)\end{array}$ & $\begin{array}{l}\text { Implementation of the Cash } \\
\text { Revenue System: A Case } \\
\text { Study in the Local } \\
\text { Government Task Forces' } \\
\text { Units of North Sumatera } \\
\text { Province, Indonesia }\end{array}$ & $\begin{array}{l}\text { Case studies related to } \\
\text { regional financial } \\
\text { management will be } \\
\text { easy, fast and accurate } \\
\text { when its computerized } \\
\text { with the help of the } \\
\text { regional financial } \\
\text { management application } \\
\text { software. }\end{array}$ & $\begin{array}{l}\text { With a reliable IT support, then the } \\
\text { rules of financial accountability to be a } \\
\text { contributing factor to realize the } \\
\text { adequacy of disclosure and can create } \\
\text { the effectiveness of internal control } \\
\text { systems. }\end{array}$ \\
\hline $\begin{array}{l}\text { Wibowo, Dedye } \\
\text { Priyo (2013) }\end{array}$ & $\begin{array}{l}\text { An Analysis of Factors } \\
\text { Affecting The Reconciliation } \\
\text { Timeliness on SAI Data by } \\
\text { the Task Force Units (A } \\
\text { Study in the Task Force Units } \\
\text { in Malang Treasury Office) }\end{array}$ & $\begin{array}{l}\text { Budget Ceiling, the } \\
\text { amount of spending, } \\
\text { assets, education, } \\
\text { experience, training, } \\
\text { number of repairs, up to } \\
\text { date applications of } \\
\text { Authorized Budget } \\
\text { Accounting Systems } \\
\text { (SAKPA) and the use of } \\
\text { electronic reconciliation. }\end{array}$ & $\begin{array}{l}\text { The formed factors, thus a panel data } \\
\text { analysis } \\
\text { resulted that the human resource } \\
\text { capacity significantly affect the } \\
\text { timeliness of SAI data reconciliation }\end{array}$ \\
\hline $\begin{array}{l}\text { Rahman, Aulia } \\
\text { et al. (2012) }\end{array}$ & $\begin{array}{l}\text { The Effect of Competence, } \\
\text { Training and Agency } \\
\text { Accounting System on the }\end{array}$ & $\begin{array}{l}\text { Competence, Training } \\
\text { and Agency Accounting } \\
\text { Systems and Quality on }\end{array}$ & $\begin{array}{l}\text { Competence, training and the } \\
\text { agencies' accounting systems } \\
\text { simultaneously affect the quality of }\end{array}$ \\
\hline
\end{tabular}




\section{Macrothink Mnstitute}

\begin{tabular}{|c|c|c|c|}
\hline & $\begin{array}{l}\text { Quality of Financial } \\
\text { Reporting Accountability on } \\
\text { Deconcentration Fund (A } \\
\text { Study on Task Force Units of } \\
\text { Aceh Government in } \\
\text { Managing Deconcentration } \\
\text { Funds) }\end{array}$ & $\begin{array}{l}\text { Accountability of } \\
\text { Financial Statements }\end{array}$ & $\begin{array}{l}\text { financial reporting accountability } \\
\text { deconcentration on the task force units } \\
\text { of Aceh Government. }\end{array}$ \\
\hline $\begin{array}{l}\text { Aliyah, Siti and } \\
\text { Aida Nahar } \\
\text { (2012) }\end{array}$ & $\begin{array}{l}\text { The Influence of Regional } \\
\text { Financial Statements and } \\
\text { Accessibility of Regional } \\
\text { Financial Statements on } \\
\text { Transparency and } \\
\text { Financial Management } \\
\text { Accountability in Jepara } \\
\text { regency }\end{array}$ & $\begin{array}{l}\text { Presentation of Regional } \\
\text { Financial Statements } \\
\text { (X1) and Accessibility } \\
\text { of Regional Financial } \\
\text { Report (X2) and } \\
\text { Transparency and } \\
\text { Management } \\
\text { Accountability of } \\
\text { Regional Financial (Y) }\end{array}$ & $\begin{array}{l}\text { Presentation of the regional financial } \\
\text { statements has a positive and } \\
\text { significant effect on the accountability } \\
\text { reports that can be read and } \\
\text { understood. Presentation of a complete } \\
\text { financial statements in accordance } \\
\text { with the standard accounting } \\
\text { administration and easily accessible to } \\
\text { all respective parties is enable to } \\
\text { control and supervise the financial } \\
\text { management appropriately. }\end{array}$ \\
\hline
\end{tabular}

\subsection{Conceptual Framework}

The conceptual framework of this study is formulated as follows:

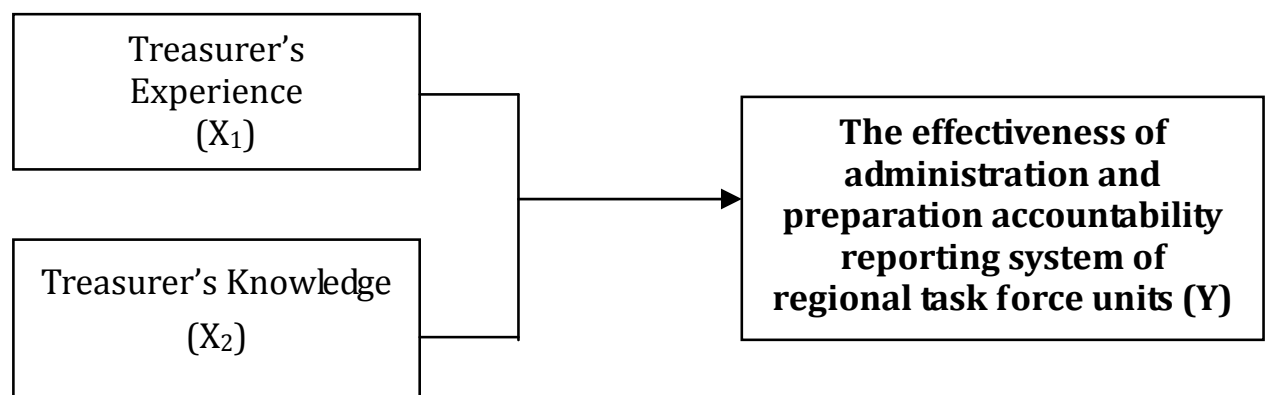

Figure 1. Conceptual Framework

\subsection{Hypothesis}

The hypothesis of this study is established as follows:

1. The experience and knowledge of task force units' treasurers on Permendagri No.55/2008 affect the effectiveness of the administration and preparation of the accountability reporting system.

2. The administration and accountability report system in accordance with Permendagri No.55/2008 has effectively been done or otherwise. 


\section{Methodology}

This study uses an explanatory, survey-type of research that aims to explain a relationnship of a phenomenon using primary data. Meanwhile, the collection of data uses questionnaires that consist of; a number of demographic variables and other questions related to the researches' variables. Meanwhile, the population of this study has included all the treasurers (receipt and spending) on the new expanded regional governments, namely: Batu Bara, Padang Lawas, South Labuhan Batu and North Labuhan Batu districts in which, as many as 168 people with a sample of 115 people had been derived from the purposive random sampling.

\subsection{Operational of Definitions and Measurement of Research Variables}

The variables consist of independent variables and dependent variable which are defined in the following table:

Table 2. Operational of Definitions and Measurement of Variables

\begin{tabular}{|c|c|c|c|}
\hline Variable & Operational of Definitions & Measurement & Scale \\
\hline \multicolumn{4}{|l|}{ Dependent } \\
\hline $\begin{array}{l}\text { The effectiveness of } \\
\text { administration and } \\
\text { preparation accountability } \\
\text { reporting system of } \\
\text { regional task force units } \\
\text { (Y) }\end{array}$ & $\begin{array}{l}\text { Accuracy and relevancy of } \\
\text { presentation of the treasurer's } \\
\text { accountability for the task force } \\
\text { units' financial statements and } \\
\text { support of regional government } \\
\text { financial statements. }\end{array}$ & $\begin{array}{l}\text { a. Effectiveness of financial statements } \\
\text { prepared by the task force units onsists of } \\
\text { budget realization report, balance sheet } \\
\text { and notes to financial statements. } \\
\text { b. Relevancy in receipts and spending. } \\
\text { c. Timely receipts and spending } \\
\text { d. Accurate receipts and spending } \\
\text { e. Complete receipts and spending. } \\
\text { f. The task force units' financial } \\
\text { statements prepared not later than } 2 \\
\text { months after the fiscal year ends and } \\
\text { regional government financial reports } \\
\text { prepared at least } 3 \text { (three) months after } \\
\text { the fiscal year ends. }\end{array}$ & Interval \\
\hline \multicolumn{4}{|l|}{ Independent Variable } \\
\hline $\begin{array}{l}\text { Experience } \\
\left(\mathrm{X}_{1}\right)\end{array}$ & $\begin{array}{l}\text { Experience of Treasurer's Tenure } \\
\text { of Service. }\end{array}$ & $\begin{array}{l}\text { - } \quad \text { Formal and Non-formal Education } \\
\text { - } \quad \text { Tenure of Service } \\
\text { - } \quad \text { Socialization, Training and } \\
\text { Workshop }\end{array}$ & Interval \\
\hline $\begin{array}{l}\text { Treasurer's Knowledge } \\
\left(\mathrm{X}_{2}\right)\end{array}$ & $\begin{array}{l}\text { Knowledge and understanding of } \\
\text { the treasurer on accountability } \\
\text { system according Permendagri } \\
\text { No.55/2008 }\end{array}$ & $\begin{array}{l}\text { - Administrative Accountability } \\
\text { System } \\
\text { - } \quad \text { Functional Responsibility } \\
\text { - } \quad \text { Preparation Accountability Report } \\
\text { System } \\
\text { - } \quad \text { Recording of Cash Receipts and }\end{array}$ & Interval \\
\hline
\end{tabular}




\begin{tabular}{|l|l|l|l|}
\hline & & $\begin{array}{l}\text { Spendings System } \\
-\quad \text { The Cash Receipts and Spendings } \\
\text { Through Treasurer Bank Account } \\
\text { System } \\
-\quad \text { The Cash Receipts and Spendings } \\
\text { Through Treasurer's Receipts Bank } \\
\text { Account of Cash General Regional } \\
\text { System } \\
\end{array}$ \\
& $\begin{array}{l}\text { The Receipts Through Cash Account } \\
\text { of General Regional System } \\
-\quad \text { The Receipt of Cash Deposit System }\end{array}$ \\
\hline
\end{tabular}

\subsection{Hypothesis Test}

To test the proposed hypothesis, the multiple regression test with a mathematical form works as follows:

$$
\mathbf{Y}=\mathbf{a}+\mathbf{b}_{1} \mathbf{X}_{1}+\mathbf{b}_{2} \mathbf{X}_{2}+\mathbf{e}
$$

Where:

$\mathrm{Y}=$ The effectiveness of administration and preparation accountability reporting system

$\mathrm{X}_{1} \quad$ Experience

$\mathrm{X}_{2} \quad=$ Knowledge and Understanding

a $=$ Constant

$\mathrm{b} \quad=$ Regression Coefficient

$\mathrm{e} \quad=$ Error

The confirmatory factor analysis for the indicator model will generate a coefficient called the loading standard or lambda value $(\lambda)$. The lambda values are used to assess the appropriateness of the instruments in the form of a factor. Meanwhile, the analysis using SEM WarpPLS requires several fit indices to measure the accuracy of the proposed model. There are some suitability indices and the cut-off values in testing the acceptance or rejection of a model (feasibility test model) among others; the effect size, output combined loadings and cross loadings, output pattern loading and cross loading, output indicator weight, output latent variable coefficient, Q squared (Stoner-Geisser coefficient), full collinearity test, output correlations among latent variables, output block VIF, Output correlation among indicators and output indirect and total effect if needed (Kock, 2013).

\section{Findings and Discussion}

\subsection{Description of Data}

There were 115 questionnaires distributed to respondents in Batubara district (20 respondents), Padang Lawas district (25 respondents), South Labuhan Batu district (32 respondents), and 


\section{Macrothink}

Asian Journal of Finance \& Accounting ISSN 1946-052X 2014, Vol. 6, No. 2

North Labuhan Batu district (27 respondents). The detail of this distribution is illustrated in the following Table:

Table 3. Distribution of Questionnaires

\begin{tabular}{lll}
\hline Particular & Total & Percentage \\
\hline Distributed Questionnaires & 115 & $100 \%$ \\
\hline Returned Questionnaires & 93 & $80.87 \%$ \\
\hline Unreturned Questionnaires & 22 & $19.13 \%$ \\
\hline Questionnaires Analysized in the Research & 93 & $80.87 \%$ \\
\hline
\end{tabular}

Source: Data Output (2014)

\subsection{Analysis on the Test of Qualitative Data}

\subsubsection{Validity Test}

From the 142 distributed questionnaires, the output's combined loadings and cross loading are used as the indicators of the convergent validity, which is part of the measurement model in SEM-PLS (Kock, 2013). The output is expected to show the constructs on the column and the indicators on the row which have obtained the results as follows: 
Table 4. Output Combined Loadings and Cross-Loading

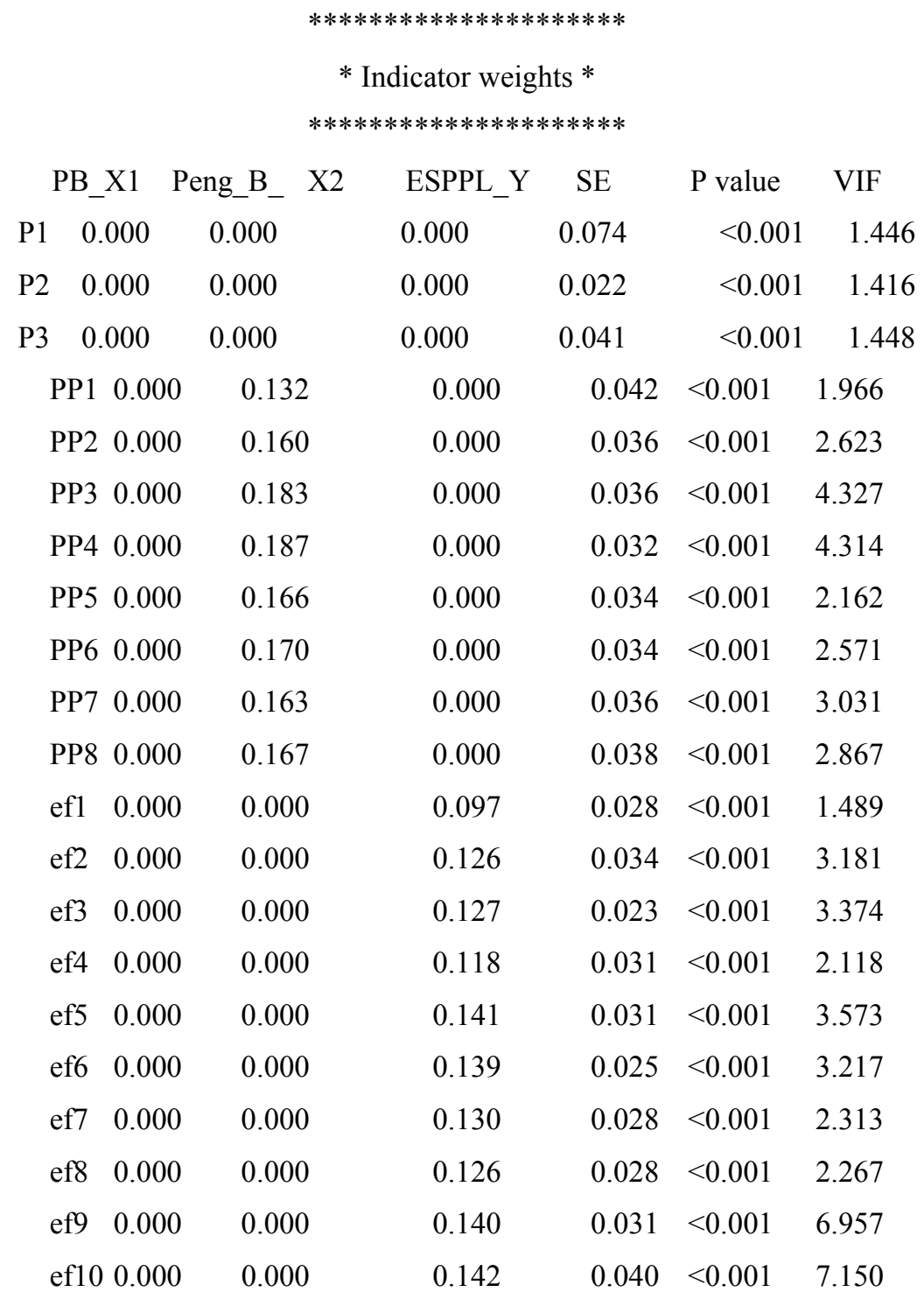

Note: P values $<0.05$ and VIFs $<2.5$ are desirable for formative indicators.

Source: Data Output WarpPLS 3.0. (2014).

Based on the results above, it indicates that the outer model qualifies for the convergent validity of the reflective constructs, except for the indicator of $\mathrm{p} 2$ where it has found an insignificant $\mathrm{p}$-value. Thus, it needs to make an elimination of $\mathrm{p} 2$. Meanwhile, the loading value above 0.70 and significant $p$-value of $>0.05$ indicate that the outer model has fulfilled the convergent validity of the reflective constructs (Hair et al., 2013). This construct test qualifies the requirement of the convergent validity and loading into another construct to be lower than that into the earlier construct.

\subsubsection{Reliability Test}

Based on the output of WarpPLS, the reliability test is as follows: 


\section{Cronbach's alpha coefficients}

$\begin{array}{ccc}\text { PB_X1 } & \text { Peng_B_X2 ESPPL_Y } \\ 0.704 & 0.886 & 0.924\end{array}$

Based on the reliability test on the 2 constructs, it obtains the Cronbach's Alpha above $60 \%$, thus all the questions are proven reliable.

\subsection{Goodness of Fit Model Test}

The indicators of the model fit are based on three indicators; the average path coefficient (APC), the average R-Squared (ARS) and the average variance inflation factor (AVIF). The P value is given to both indicators of APC and ARS that is computed by the resampling estimation and Bonferroni-like correction (Sholihin \& Ratmono, 2013). The results show:

\section{Model Fit Indices and P values}

$$
\begin{gathered}
\mathrm{APC}=0.250, \mathrm{P}<0.001 \\
\mathrm{ARS}=0.167, \mathrm{P}=0.044 \\
\mathrm{AVIF}=1.059, \text { Good if }<5
\end{gathered}
$$

Source: Result Test of WarpPLS, 2014.

Thus, both the APC and the ARS values are significant at the alpha level of below $5 \%$ and the AVIF value is below the value of 5, indicating that the model is fit.

\subsection{Classical Assumption Test}

Testing the classical assumptions are done to determine that the regression models are acceptable econometrically. They are the normality, multicollinearity and heteroscedasticity tests.

\subsubsection{Normality Test}

Based on the test results for normality using the Kolmogorov Smirnov test and by looking at the graph, it is concluded that the residuals are normally distributed. If the probability value Asymp. Sig (2-tailed) on the Kolmogorov Smirnov test is greater than 0.05, it can be stated that the data are normally distributed, otherwise if the probability Asymp. Sig (2-tailed) is less than 0.05 , thus the data are not normally distributed (Ghozali, 2009). 


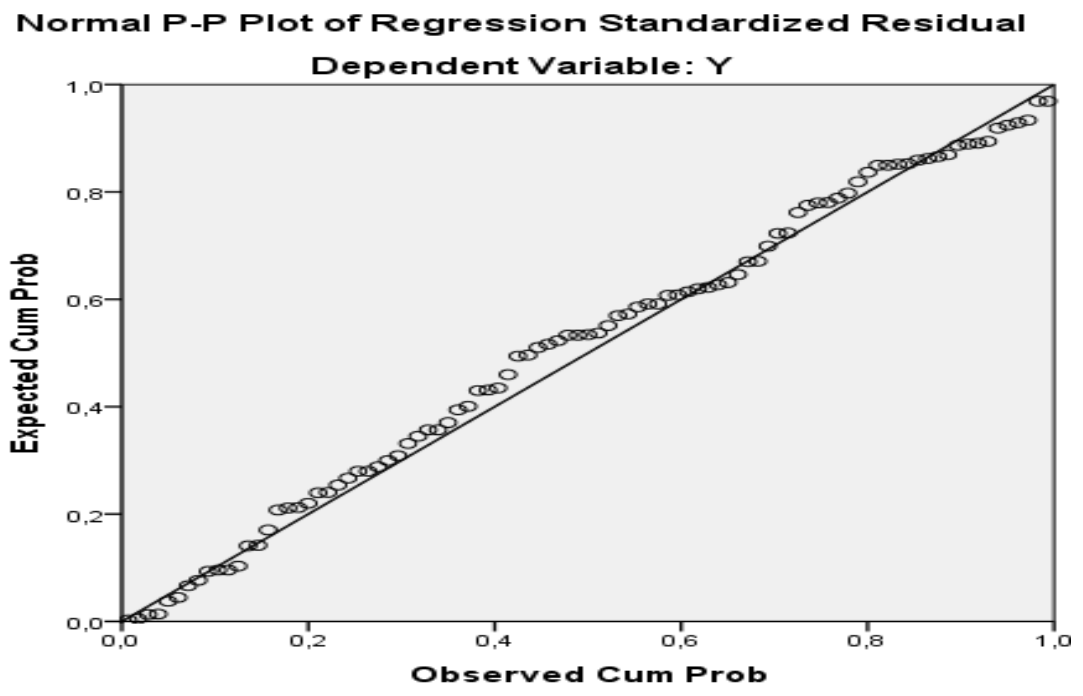

Figure 2. Normal P-Plot of Regression Standardized Residual

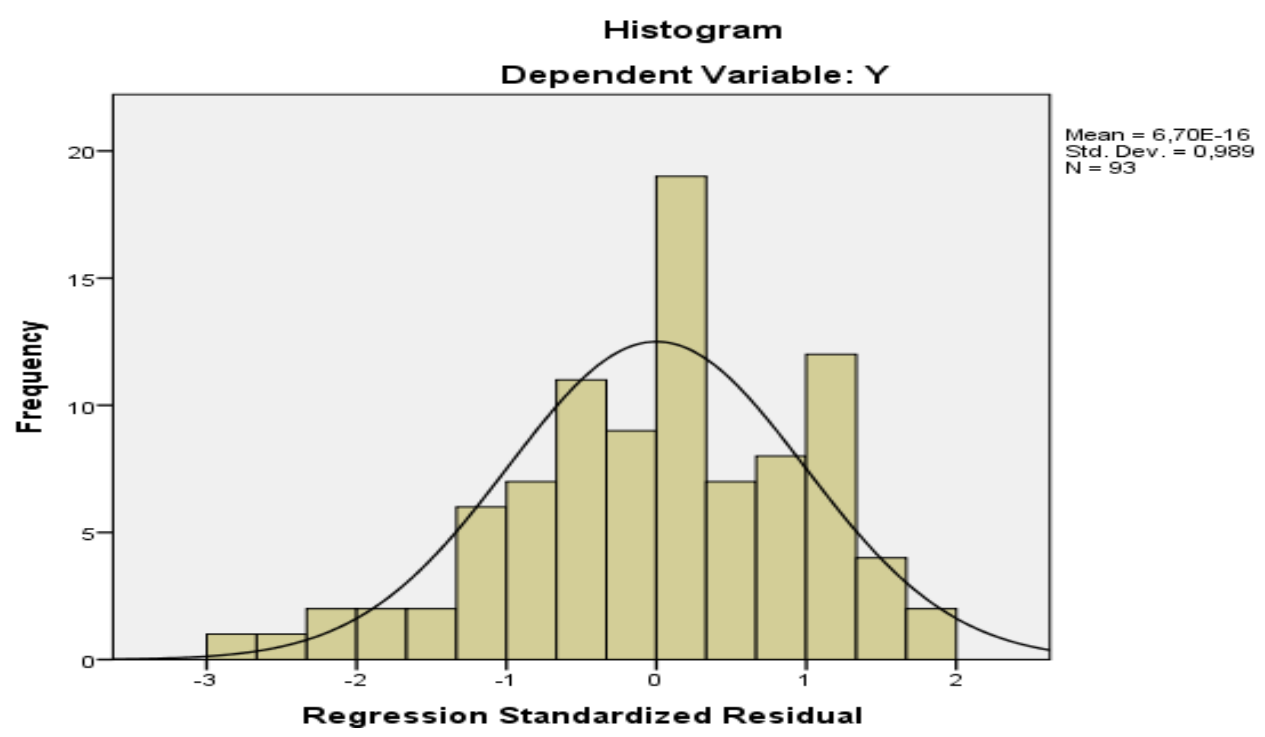

Source: Data Output SPSS

Figure 3. Histogram

By looking at the graphs displayed in Figure 2, it can be concluded that the data spread around the diagonal line, and follow the direction of its diagonal line. This shows that the data residuals are normally distributed. Similarly, with the results of the histogram graph in Figure 3, it shows that the data residuals are normally distributed which can be seen from the picture in a bell form that is almost perfect (symmetrical).

\subsubsection{Multicollinearity Test}

Based on the results of the correlation test between the independent variables by looking at the value of the VIF, it is concluded that the multicollinearity problem does not occur. This is supported by the Full Collon value. The VIF is relatively small; not greater than 3.3 (Kock, 2013). The results indicate that the independent variables do not occur in multicollinearity, 


\section{Macrothink}

whereby the AVIF results are all smaller than 5, justifying that the model is qualified for the classical assumption in the regression analysis.

Table 5. Multicollinearity Test Result

\section{Full collinearity VIFs}

\section{PB_X1 Peng_B_ESPPL_Y

$1.080 \quad 1.164 \quad 1.188$

Source: Result Output of WarpPLS 3.0. (2014)

\subsubsection{Heteroscedasticity test}

The test result has concluded that the heteroscedasticity did not occur in the regression model. It can be seen from the scatterplot in which the points are spread randomly or that they do not form a specific pattern clearly, and scattered both above and below 0 on the Y axis (Ghozali, 2009).

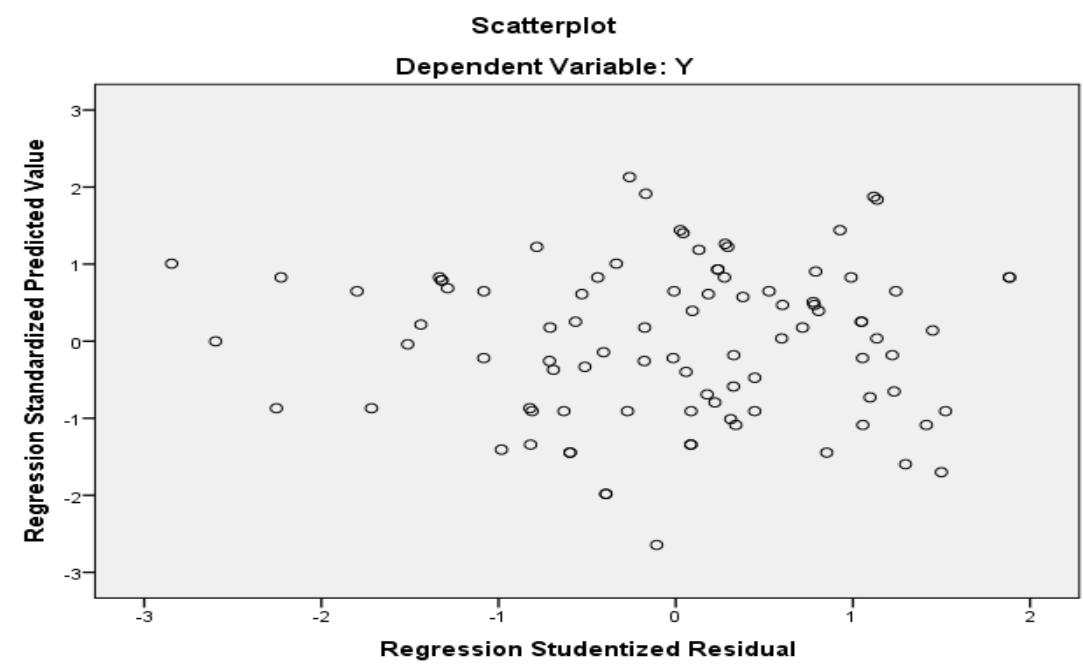

Figure 4. Scatterplots Graph

\subsection{Hypothesis Test}

Several hypotheses proposed in this study are as follows:

1. The experience and knowledge of treasurers' task force units on Permendagri No.55/2008 affect the effectiveness of the administration and preparation of the accountability reporting system.

2. The effectiveness of the administration and preparation of the accountability reporting system in accordance with Permendagri No.55/2008 has been running effectively.

The results of testing on the first hypothesis are unacceptable. To test the coefficient on individual partial regression of each independent variables can be seen in the following figure: 


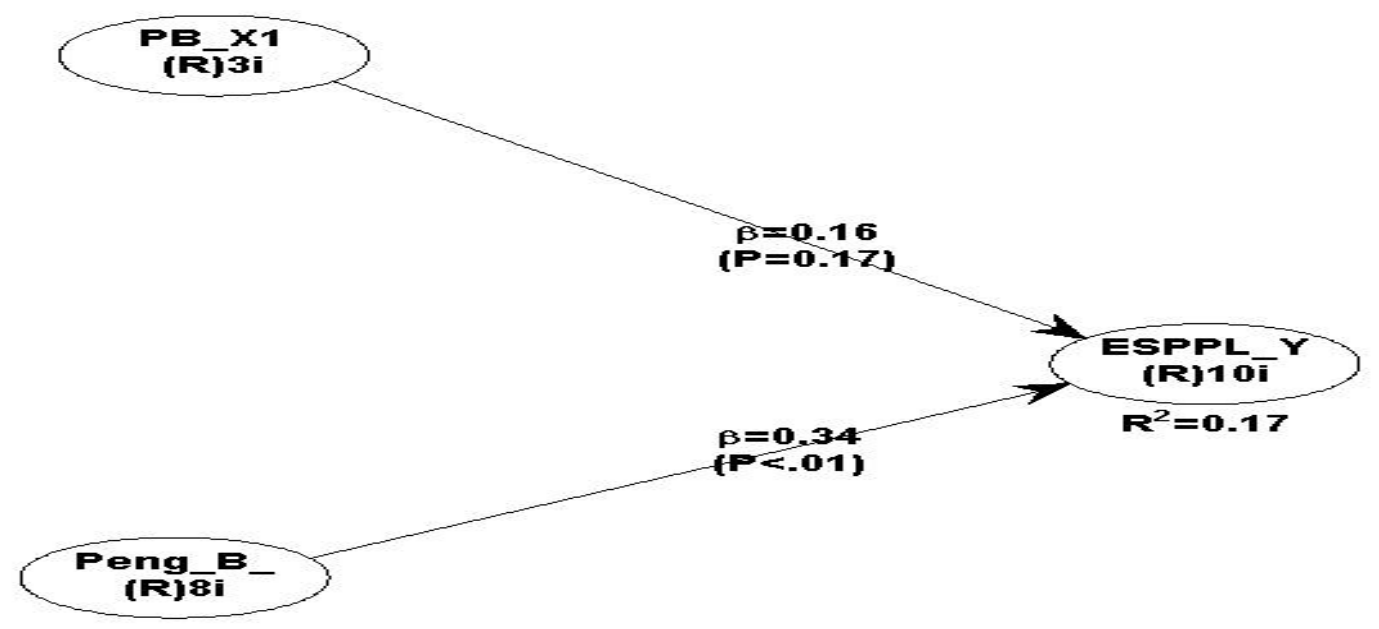

Figure 5. Result Output of WarpPLS 3.0.

From the Structural Equation Modeling of the Figure 5, the t-test statistic is obtained as follows:

1. The experience variable $\left(\mathrm{X}_{1}\right)$ with a beta value of 0.16 and the $\mathrm{p}$-value with 0.10 probability level. Thus, it can be concluded that $\mathrm{p}=0.17>\alpha=0.05$, and we accept $\mathrm{H} 0$ and reject Ha, whereby experience does not affect the effectiveness of the administration and preparation of the accountability reporting system.

2. The treasurer's knowledge variable of task force units on Permendagri No.55/2008 $\left(\mathrm{X}_{2}\right)$ with a beta value of 0.34 and the $p$-value with a probability level of $<0.01$. It can be concluded that $\mathrm{p}=0.01<\alpha=0.05$, and H0 is rejected and Ha accepted, whereby the knowledge of treasurers' task force units on Permendagri No.55/2008 affects the effectiveness of the administration and preparation of the accountability reporting system.

With the above elaboration, the multiple regression is formulated based on the path coefficient as follows:

$$
Y=0,164 X_{1}+0,337 X_{2}+e
$$

The multiple regression model is interpreted as:

1. The experience variable $\left(\mathrm{X}_{1}\right)$ does not affect the effectiveness of the administration and preparation of the accountability reporting system with the coefficient value of 0.164 , meaning that each additional unit on the value of the experience variable score will raise the value of one unit of creation effectiveness of the administration and preparation of the accountability reporting system for 1.64 units.

2. The treasurer's knowledge variable of task force units on Permendagri No.55/2008 $\left(\mathrm{X}_{2}\right)$ affects the effectiveness of the administration and preparation of the accountability reporting system with the coefficient value of 0.337 , meaning that each additional unit of the value of the treasurer's knowledge variable score, will raise the value of one unit of creation effectiveness of the administration and preparation of the accountability reporting system by 3.37 units. 


\subsection{The Result Test of Determinant Coefficient $\left(R^{2}\right)$}

The determinant coefficient is used to test the goodness-fit of the regression model that is seen from the value of $\mathrm{R}$ Square. $\mathrm{R}$ square is the means for the endogenous construct. For a set of latent predictor variables on the criterion variable, an indicator of Q-Squares or any other terms called the Stoner-Geisser coefficient (Sholihin \& Ratmono, 2013, p. 72) are used. Determining the effect of variables; treasurer's experience and knowledge on the effectiveness of the administration and preparation of the accountability reporting system can be seen on the greater value of Q-Squares coefficient on the results output of WarpPLS 3.0.

Table 6. R-Square Coefficient

\begin{tabular}{|c|c|c|c|}
\hline No & PB_X $X_{1}$ & Peng_B $\mathrm{X}_{2}$ & ESPPL_Y \\
\hline 1 & & & 0.174 \\
\hline
\end{tabular}

Source: Result Output of WarpPLS, 2014.

Based on the calculation above, the Q-Squared coefficient value is 0.174 . This means that $17.4 \%$ of the variables; treasurer's experience and knowledge on Permendagri No. 55/2008 on the effectiveness of the administration and preparation of the accountability reporting system can be explained by both independent variables, while the remaining $82.6 \%$ is explained by other factors outside the model. The estimated models show a good predictive validity of $17.4 \%$.

For the second problem related to the implementation on the effectiveness of the administration and preparation of the accountability reporting system in accordance with Permendagri No.55/2008, it can be viewed from the respondents' scores found in the variable of the effectiveness of the administration and preparation of the accountability reporting system (Y), where there are 10 items of questions that have to achieve the maximum answer values of 50 . The tabulation results of 93 respondents indicate the maximum response that reached 49 points and the lowest minimum that reached 22 points. The average response value reached 36.58 with a standard deviation of an average of 6.03. Thus, the intensity of the average respondents' responses was close to 'strongly agreed', which means lower effectiveness because it only reached $36.58 \%$.

\subsection{Discussion}

The hypothesis that the variables of treasurer's experience and knowledge of task force units on Permendagri No.55/2008 affect the effectiveness of the administration and preparation of the accountability reporting system is acceptable. The results of this study contradict (inconsistent) the results found by Pangkong et al. (2013) showing that experience is the dominant factor which determines the effectiveness of the administration and preparation of the accountability reporting system. Without an experience, then all tasks done are unable to determine the direction. The higher the experience, the greater the determination of the 
effectiveness underlying the administration and the preparation accountability reporting system. Regulations can be applied in such a way and can be run based on the experience of implementing the activities. Meanwhile, the activities of data processes, collection, recording and summarizing alongside the financial reporting responsibilities within the framework of the implementation on each of the task force units have been well-performed, based on the understanding of the treasurers. The understanding covers the use of certain documents as the basis of recording among others; payment for the certificate, using credit notes and legal receipts and filling in the certificate of deposit.

\section{Conclusion and Recommendation}

The conclusions of this research are:

1. The experience variable does not affect the effectiveness of the administration and preparation of the accountability reporting system. The results are inconsistent with the findings found by Pangkong et al. (2013).

2. The treasurer's knowledge of the task force units on Permendagri No. 55/2008 affects the effectiveness of the administration and preparation of the accountability reporting system. These contradict the results established by Pangkong et al. (2013).

Meanwhile, the suggestions of this study for further activities are:

1. In the future, it is necessary to acknowledge that experience is not a factor that determines the success of accountability reporting, while other factors such as the commitment of the Head of task force units and the policies of accounting and internal control that are applied to the treasurers of task force units used to be a critical success factor.

2. Moreover, concerning the knowledge on the Permendagri No. 55/2008, it needs to be strengthened in the form of training and technical assistance as a reinforcement that can benefit the receipt and spending treasurers.

\section{References}

Aliyah, S., \& Aida N. (2012). Pengaruh Penyajian Laporan Keuangan Daerah dan Aksesibilitas Laporan Keuangan Daerah Terhadap Transparansi dan Akuntabilitas Pengelolaan Keuangan Daerah Kabupaten Jepara. Jurnal Akuntansi \& Auditing, 8(2), 97-189.

Avazzadehfath, F., Raiashekar. (2011). Decision-Making Based on Human Resource Accounting Information and It's Evaluation Method. Asian Journal of Finance \& Accounting, 3(1), 52-96. http://dx.doi.orgg/10.5296/ajfa.v3i1.881.

Hair, J., Hult, T., Ringle, C., \& Sartstedt, M. (2013). A Primer on Partial Least Squares Structural Euation Modeling (PLS-SEM). Los Angles: Sage.

Hall, James A. (2013). Accounting Information Systems. The Eighth Edition. Prentice Hall. New York.

Haryanto. (2013). Pengelolaan dan Akuntansi Keuangan Daerah. Semarang: Undip Press. 
Ghozali, I. (2009). Aplikasi Analisis Multivariate dengan Program SPSS. Universitas Diponegoro. Semarang.

Kock, N. (2013). Advanced Mediating Effects Tests, Multi-Group Analyses, and Measurement Model Assessments in PLS-based SEM. ScriptWarp Systems- Laredo, Texas USA.

Kim, S. (2005). Individual Level Factors and Organizational Performance in Government Oganizations. Journal of Public Administration Research and Theory, 15, 245-261. http://dx.doi.org/10.1093/jopart/mui013

Kengatharan, L., \& Navaneethakrishnan, K. (2014). The Influence of Behavioral Factors in Making Investment Decisions and Performance: Study on Investors of Colombo Stock Exchange, Sri Lanka. Asian Journal of Finance \& Accounting. 6(1), 48-53. http://dx.doi.org/10.5296/ajfa.v6i1.4893.

Melati, I.I. (2011). Faktor-faktor yang Mempengaruhi Kinerja Pegawai: Studi Empiris pada Kementerian Keuangan Jawa Tengah. E-journal Undip Semarang.

Muda, I., \& Rasdianto, M. S. L. (2014). Implementation of the Cash Revenue System: A Case Study in the Local Government Task Forces' Units of North Sumatera Province, Indonesia. Information Management \& Business Review, 6(2)

Nilawati, Ivon. (2009). Kajian Keterlambatan Laporan Pertanggungjawaban Pengeluaran Satuan Kerja Perangkat Daerah (SKPD) Di Kabupaten Lampung Tengah Tahun 2008. Jurnal On line Universitas Indonesia.

Rahman, A., Darwanis, \& Siswar, D. (2012). Pengaruh Kompetensi, Pelatihan dan Sistem Akuntansi Instansi terhadap Kualitas Pertanggungjawaban Laporan Keuangan Dana Dekonsentrasi (Studi Pada Satuan Kerja Pemerintah Aceh yang Mengelola Dana Dekonsentrasi). Jurnal Akuntansi Pascasarjana Universitas Syiah Kuala Banda Aceh, 2(1).

Pangkong, T.C., David, P.E.S., \& Jullie, J.S. (2013). Faktor-Faktor yang Mempengaruhi Kemampuan Penyusunan Laporan Keuangan Pemerintah Daerah di Kabupaten Biak Numfor. Jurnal Riset Akuntansi dan Auditing, 4(1), 157-170.

Robbins, S.P., \& Judge. (2007). Perilaku Organisasi. Edisi Ke-10. Terjemahan Benyamin Molan. Jakarta: PT Indeks.

Sholihin, M., \& Ratmono, D. (2013). Analisis SEM-PLS dengan WarpPLS 3.0 untuk Hubungan Non Linier dalam Penelitian Sosial dan Bisnis. Penerbit Andi Yogyakarta.

Siegel, S., \& Marcony. (1989). Non-Parametric Statistics. New York: McGraw Hill.

Wibowo, Dedye Priyo. (2013). Analisis Faktor-Faktor yang Mempengaruhi Waktu Penyelesaian Rekonsiliasi Data Sai Satuan Kerja (Studi pada Satuan Kerja di Wilayah Kerja KPPN Malang). Jurnal On Line Universitas Brawijaya Malang. 